[Agr. Biol. Chem., Vol. 29, No. 1, p. 20 26, 1965]

\title{
Studies on the Metabolism of Gallic Acid by Microorganisms
}

\author{
Part III. On the Intermediary Metabolism of Gallic Acid \\ by Aspergillus niger \\ By Akira Watanabe \\ Department of Agricultural Chemistry, Faculty of Agriculture, \\ University of Kyushu, Fukuoka* \\ Received July 4, 1964
}

\begin{abstract}
The intermediary metabolism of gallic acid by Aspergillus niger under the influence of some added inhibitors has been studied. The decomposition of gallic acid by lyophilized cells under fluoroacetate inhibition allowed cis-aconitic acid, $\alpha$-ketoglutaric acid and citric acid to accumulate. A mechanism of gallic acid decomposition via cis-aconitic acid has been inferred.
\end{abstract}

In the previous paper the author reported the formation and some properties of the gallic acid(GA)-decomposing enzyme of $A s^{-}$ pergillus niger s-2I." The enzyme could not be extracted in a cell-free state and the lyophilized cells were the most active preparation.

Previously the intermediary metabolism of phenolic compounds by Aspergillus niger has been studied by Friedrich. ${ }^{2}$ ' Under the arsenite inhibition, levulinic acid was identified in the enzymatic digest of resorcin and hydroquinone, and $\beta$-ketoadipic acid was considered to be an intermediate, but no intermediate was identified in the case of GA and pyrogallol.

In this paper, the intermediary metabolism of GA by the lyophilized cells of Aspergillus niger s-2I in the presence of enzyme inhibitors was studied and the mechanism of GA decomposition was discussed.

\section{EXPERIMENTALS AND RESULTS}

Materials and Methods.

1) Mycellium: The lyophilized cells and the

* Present address, Tokyo Research Laboratory (Tanabe Seiyaku Co., Ltd., Shimotoda, Toda-machi, Saitama.)

1) A. Watanabe, J. Agr. Chem. Soc. Japan, 37, 469 (1963)

2) H. Friedlich. Arch, für Microbiol., 25, 297 (1956) aceton-dried cells were prepared from the cells which had been adapted to the decomposition of GA as described previously.11

2) Compounds: For pure cis-aconitic acid could not be obtained from commercial source, it was synthesized from trans-aconitic acid by the Malachowski's method $^{3)}$ modified by Tomisawa.4) m.p. $127^{\circ} \mathrm{C}$. Trans-aconitic acid was synthesized from citric acid by the method of Bruce. ${ }^{5)} \mathrm{m} . \mathrm{p} .198^{\circ} \sim 198.5^{\circ} \mathrm{C}$. The other reagents used were of analytical grade.

3) Incubation for decomposition: Cell preparations were suspended in $0.1 \mathrm{M}$ or $1 \%$ aqueous solution of GA, which was dissolved at $\mathrm{pH} 5.5$ by addition of $2 \mathrm{~N} \mathrm{NaOH}$, and the reaction mixture was incubated at $40^{\circ} \mathrm{C}$ with shaking in a Erlenmeyer flask or under aeration in a jar fermenter.

4) Estimation of GA decomposition: Decomposition of GA was estimated by the colorimetric determination of remaining GA as described previously.6?

5) Ether extraction of the decomposition products: The incubation mixture was filtered and the cells were washed thoroughly with water of about half the volume of incubation mixture. The filtrate and washings were combined and brought to $\mathrm{pH} 2.0$

3) R. Malachowski and M. Maslowski, Ber, 61, 2521 (1928).

4) J. Tomisawa, "Hyojun Seikagaku Jikken"' (Standard Experiments of Biochemistry) Kobundo, Tokyo, 1953, p. 568 .

5) W. F. Bruce, Org. Syn., 17, I.

6) A. Watanabe, J, Agr. Chem. Soc. Japan, 37, 464 (1963). 
with $4 \mathrm{~N}_{2} \mathrm{SO}_{4}$. The decomposition products were then extracted with ether by means of a liquid-liquid extractor for one hundred and twenty hours. The ether extracts of about four times the volume of incubation mixture were dried with sodium sulfate, concentrated to dryness under vacuum, and used for identification of intermediates.

\section{Preliminary Experiments.}

Since it was considered that, in the acetone-dried or lyophilized cell, a part of the enzyme system might have been denatured and the permeability of the cell membrane would have increased, the decomposition products of GA by these cell preparations were examined. The reaction mixture was extracted with ether at $\mathrm{pH} 2.0$ for one hundred and twenty hours and the components of the ether extract were examined by paperchromatography. Notable quantities of decomposition products such as phenolic compounds and organic acids were not found. Only in the case of the acetone-dried cell, a trace of acidic substance resulting from the degradation of $5 \mathrm{~g}$ of $\mathrm{GA}$ was found in the ether extract but could not be identified because of its small quantity. Thereupon, effects of inhibitors on the GA-decomposition were studied. Based on the knowledge of some other aromatic nucleus-degrading enzymes such as pyrocatechase ${ }^{7)}$ and protocatechuic acid oxidase, 8 ) the inhibitors studied included inhibitors for SH-enzymes, some metal-binding agents and others. In a 100-ml Erlenmeyer flask, $0.5 \mathrm{~g}$ of lyophilized cells, $5 \mathrm{ml}$ of $0.1 \mathrm{M}$ GA solution and an amount of an inhibitor to give a final concentration of $0.001 \mathrm{M}$ were mixed in a final volume of $50 \mathrm{ml}$ at $\mathrm{pH} 5.5$. After incubation on a recipro.

\section{TABLE 1. EFFECTS OF INHIBITORS ON GA DECOMPOSITION}

$\begin{array}{lc}\text { Inhibitor }\left(10^{-3} \mathrm{M}\right) & \text { Inhibition degrec }(\%) \\ p \text {-CMB } & 75 \\ \text { EDTA } & 0 \\ \alpha \alpha^{\prime} \text {-Dipyridyl } & 45 \\ \mathrm{NaN}_{3} & 0 \\ \mathrm{CuSO}_{4} & 29 \\ \mathrm{NaHSO}_{3} * & 98 \\ \text { Iodoacetate } & 13 \\ \text { Arsenite } & 13 \\ \text { Fluoroacetate } & 7 \\ \text { * Final conc. M/15. } & \end{array}$

7) O. Hayaishi, M. Katagiri and S. Rothberg, J. Biol. Chem., 229, 905 (1957).

8) L. Ottey and E.L. Tatum. ibid, 223, 307 (1956). cating shaker at $30^{\circ} \mathrm{C}$ for twenty hours, the inhibition degree for the GA-decomposition was estimated (Table I). Detection of reaction products was performed by paperchromatography with the reaction mixtures incubated with EDTA, sodium azide, fluoroacetate and arsenite, the inhibition degrees of which were comparatively low. Each ether extract from $50 \mathrm{ml}$ of the reaction mixtures was paperchromatographed on Tôyô Roshi No. 50 filter paper with two solvent systems, $n$-butanol-water-formic acid $(10: 15: 2 \mathrm{~V} / \mathrm{V})$ and phenol-water-formic acid $(75: 25: 1 \mathrm{~V} / \mathrm{V})$. After air-drying the paper, acidic intermediates were detected on the paperchromatogram by spraying $0.04 \%$ alcoholic bromphenolblue solution adjusted to $\mathrm{pH} 4.0$. It was found that the acidic intermediates accumulated most evidently in the reaction mixture of fluoroacetate inhibition and to some extent in the reaction mixture of arsenite inhibition.

Effect of variation in concentration of fluoroacetate on its inhibitory action.

At various concentrations of fluoroacetate the inhibition degree for GA decomposition was estimated. Under the conditions employed the reaction was hardly inhibited by addition of fluoroacetate less than $0.002 \mathrm{M}$ in the final concentration. When $5 \mathrm{~g}$ of the fresh

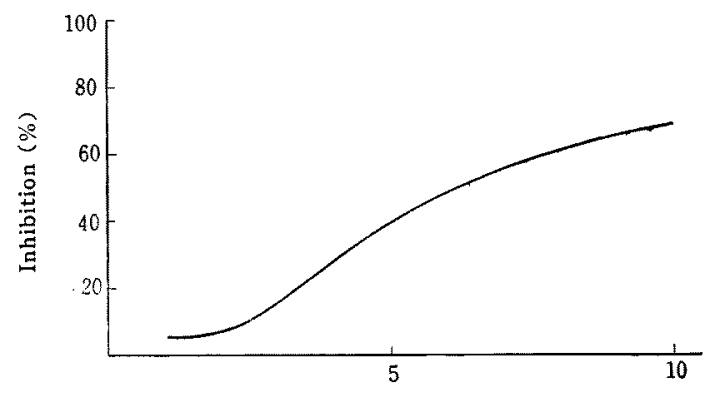

Conc. of fluoroacetate $\left(\times 10^{-3}\right)$

FIG. 1. Relationship between Concentration and Inhibitory Effect of Fluoroacetate on GA Decomposition.

adapted cells, which had about the same activity as $0.5 \mathrm{~g}$ of the lyophilized cells, and $0.002 \mathrm{M}$ fluoroacetate were used, GA was degraded completely after fifteen hours and acidic intermediates scarcely accumulated.

Extraction of Intermediates from the Reaction Mixture Inhibited by Fluoroacetate.

Forty grams of the lyophilized adapted cells was added to 31 of water containing $40 \mathrm{ml}$ of $\mathrm{M} / 3$ aqueous solution of fluoroacetate in a $10-1$ jar and suspended well. 


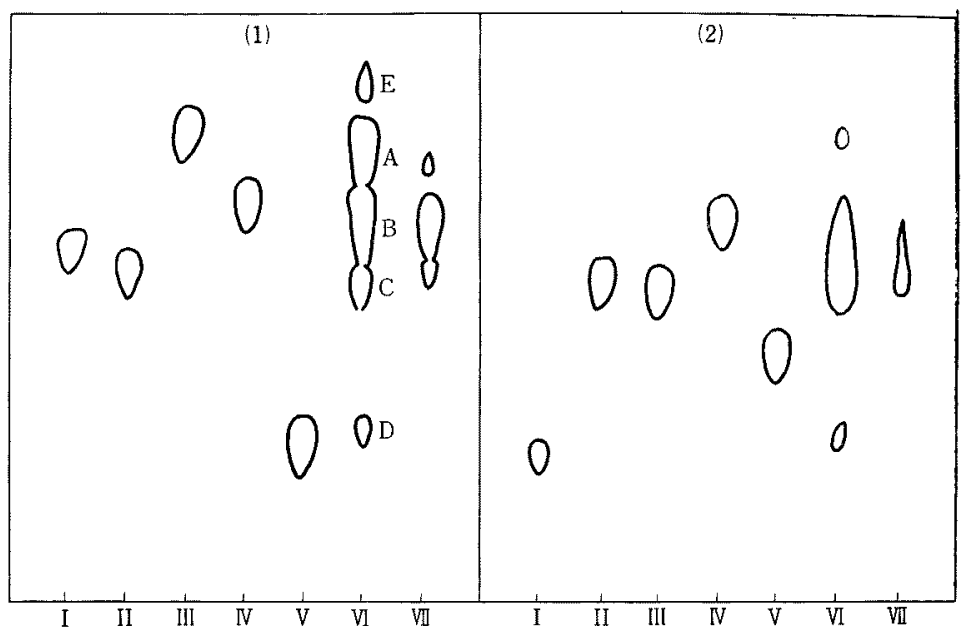

FIG. 2. Paperchromatograms of Organic Acids from the Reaction Mixtures Containing the Inhibitors.

I: GA, II: cis-aconitic acid, III: trans-aconitic acid, IV: $\alpha$-ketoglutaric acid, $\mathrm{V}$ : citric acid, VI: fluoroacetate inhibition, VII: arsenite inhibition.

(Solvent system: (1), $n$-BuOH-Water-Formic acid $(10: 15: 2) \mathrm{V} / \mathrm{V}$.

(2), Phenol-Water-Formic acid (75:25:1) $\mathrm{V} / \mathrm{V}$.

After keeping the mixture at $30^{\circ} \mathrm{C}$ for about thirty minutes, $7.6 \mathrm{~g}$ of $\mathrm{GA}$ was added as a $50 \mathrm{ml}$ aqueous solution, the $\mathrm{pH}$ of which had been adjusted to 5.5 with $2 \mathrm{~N} \mathrm{NaOH}$. The reaction was allowed to proceed at $30^{\circ} \mathrm{C}$ under aeration at the rate of 41 air per minute. During the course of reaction the $\mathrm{pH}$ was adjusted to 5.5 by addition of $2 \mathrm{~N} \mathrm{NaOH}$ and $\mathrm{GA}$ in the mixture was estimated at time intervals. GA was decomposed completely in thirty-seven hours. The reaction mixture was filtered, the cell paste homogenized in 11 water with a blender, the homogenate filtered and the residue washed with water. The filtrates and washings were all combined. The combined solution was brought to $\mathrm{pH} 7.0$ with $2 \mathrm{~N}$ $\mathrm{NaOH}$ and concentrated to 11 under vacuum. After the concentrated solution was brought to $\mathrm{pH} 2.0$ with $4 \mathrm{~N}_{2} \mathrm{SO}_{4}$ and then saturated with sodium chloride, the decomposition products were extracted with ether for one hundred and twenty hours. The ether extracts were removed from the extractor and the ether container of the extractor was washed with ether thoroughly. Four liters of the combined ether solutions dried with sodium sulfate was concentrated to dryness under vacuum, and $1.95 \mathrm{~g}$ of orange-yellow oily residue was obtained. The constituents were examined by paperchromatography and it was con- firmed that it contained no other acidic constituents than the one which was found in the preliminary experiment, and that no phenolic substances that were positive to the ferric chloride reaction were present. The substances separated on the paperchromatogram with the solvent system of $n$-butanol-water-formic acid were named $\mathrm{A}, \mathrm{B}, \mathrm{C}, \mathrm{D}$ and $\mathrm{E}$, respectively, as shown in Fig. 2.

\section{Separation of the Components of the Ether Ex-} tracts by Column Chromatography.

After examination of column chromatography with cellulose powder, silica gel ${ }^{9)}$ and celite, ${ }^{10}$ ) these acidic substances were found to be best separated by a method which consisted of the primary separation with silica gel and the rechromatography of resulting fractions with cellulose powder.

1) Silica gel column chromatography: Thirtytwo grams of activated silica gel prepared by the method of Bulen') was mixed thoroughly with $22 \mathrm{ml}$ of $0.5 \mathrm{~N} \mathrm{H}_{2} \mathrm{SO}_{4}$ and suspended in $300 \mathrm{ml}$ of chloroform which was equilibrated with $0.5 \mathrm{~N} \mathrm{H}_{2} \mathrm{SO}_{4}$. The resulting silica gel was packed in a column

9) W.A. Bulen, J.E. Varner and R.C. Burrell, Anal. Chem., 24, 187 (1952): J. E. Varner, "Method in Enzymology". Academic Press Inc., New York, 1957, Vol. III, p. 397.

10) H.E. Swin and F.M. Utter, "Method in Enzy mology". 
$(1.8 \times 24 \mathrm{~cm})$. The solution of $400 \mathrm{mg}$ of the ether extract dissolved in $1 \mathrm{ml}$ of $0.5 \mathrm{~N}_{2} \mathrm{SO}_{4}$ was adsorbed in $4 \mathrm{~g}$ of silica gel uniformly. The loaded silica gel was packed on the top of the silica gel column with about $5 \mathrm{ml}$ of chloroform equilibrated with $0.5 \mathrm{~N}$ $\mathrm{N}_{2} \mathrm{SO}_{4}$. The elution was performed at a rate of $80 \mathrm{ml}$ per hour and fractions of $10 \mathrm{ml}$ were collected. The solvent schedule was $400 \mathrm{ml}$ of $5 \%, 540 \mathrm{ml}$ of $15 \%, 400 \mathrm{ml}$ of $25 \%, 1200 \mathrm{ml}$ of $35 \%$, and $600 \mathrm{ml}$ of $50 \% n$-butanol in chloroform (V/V) which was equilibrated with $0.5 \mathrm{~N} \mathrm{H}_{2} \mathrm{SO}_{4}$ and filtered with dry filter paper. Fractions were examined by paper chromatgraphy for their components and divided into the following groups. Fractions of group 1, 2, 3 and 4 from the ether

\begin{tabular}{|c|c|c|}
\hline \multicolumn{2}{|c|}{ Groups } & Components \\
\hline 1 (fraction & $64 \sim 73)$ & $B$ with a trace of $A$ \\
\hline 2 (fraction & $74 \sim 79)$ & $A$ with a trace of $B$ \\
\hline 3 (fraction & $85 \sim 95)$ & $A$ and $C$ \\
\hline 4 (fraction & $191 \sim 204$ ) & D only \\
\hline
\end{tabular}

extract of $800 \mathrm{mg}$ which had been chromatographed in two portions were combined respectively and concentrated under vacuum. Residues of $250 \mathrm{mg}, 270 \mathrm{mg}$ and $25 \mathrm{mg}$ were obtained from group 1,2 and 3 respectively, and group 4 gave $20 \mathrm{mg}$ of semicrystallized material. E was not found in any fraction.

2) Purification of $A$ and $B$ by column chromatography on cellulose powder: The residues from group 1 and 2 were rechromatographed to remove the contaminating trace of $A$ and $B$, respectively. Then solution of $200 \mathrm{mg}$ of the residue from group 1 dissolved in $1.5 \mathrm{ml}$ of ethanol was adsorbed in $2 \mathrm{~g}$ of cellulose powder (Tôyô Roshi 100 200 mesh) and mixed thoroughly. After evaporation of ethanol under vacuum, it was packed on the top of a column of cellulose powder $(2.2 \times 47 \mathrm{~cm}, 45 \mathrm{~g}$ of cellulose powder $)$. Then the elution was performed with $n$-butanol-waterformic acid (10:15:2 V/V) at a flow rate of $20 \mathrm{ml}$ per hour. Fractions of $5 \mathrm{ml}$ were collected and the components were examined by paperchromatography with the same solvent as in the column chromatography. The solvent of fractions $30 \sim 36$ was evaporated under vacuum and $85 \mathrm{mg}$ of $\mathrm{B}$ was obtained. Similarly, $210 \mathrm{mg}$ of the residue from group 2 was chromatographed on a cellulose column of the same scale, and $120 \mathrm{mg}$ of A was obtained from fractions $24 \sim 28$ after evaporating the solvent. $C$ which was present in the effluent of group 3 was no longer found in the residue of $25 \mathrm{mg}$ after evaporation of the solvent.

\section{Identification of Intermediates.}

Each of the separated substances was examined by paperchromatography as described previously, and upon comparison with authentic substances, it was supposed that A, B and D were trans-aconitic acid, $\alpha$-ketoglutaric acid and citric acid, respectively.

1) Substance A: A was recrystallized from ethylacetate-chloroform and $85 \mathrm{mg}$ of small needles was obtained from $110 \mathrm{mg}$ of A, m. p. $194^{\circ} \mathrm{C}$. Anal. Found: C, 41.65; $\mathrm{H}, 3.59$. Calcd. for $\mathrm{C}_{6} \mathrm{H}_{6} \mathrm{O}_{6}: \mathrm{C}, 41.39 ; \mathrm{H}$, $3.47 \%$. The infrared spectra of $\mathrm{A}$ and an authentic sample of trans-aconitic acid showed no difference in absorption.

2) Substance B: B was recrystallized from acetonebenzene to give $55 \mathrm{mg}$ of crystals from $85 \mathrm{mg}$ of $\mathrm{B}$, m. p. $111^{\circ} \mathrm{C}$. To $40 \mathrm{mg}$ of $B$ dissolved in $0.5 \mathrm{ml}$ of water was added $4 \mathrm{ml}$ of $4 \%$ solution of 2,4-dinitrophenylhydrazine in methanol saturated with dried $\mathrm{HCl}$ gas. After thirty minutes, the hydrazone was precipitated by the addition of $1 \mathrm{ml}$ of water and filtered. The 2,4-dinitrophenylhydrazone was recrystallized from water, m. p. $220^{\circ} \mathrm{C}$. Anal. Found: C, 40.36; $\mathrm{H}, 3.15 ; \mathrm{N}, 16.98$. Calcd. for $\mathrm{C}_{13} \mathrm{H}_{10} \mathrm{O}_{8} \mathrm{~N}_{4} ; \mathrm{C}$, $40.50 ; 3.09 ; \mathrm{N}, 17.18 \%$. Therefore, $\mathrm{B}$ was identified as $\alpha$-ketoglutaric acid.

3) Substance C: Although A was identified as trans-aconitic acid, it has been reported that transaconitic acid does not undergo the enzymatic reaction, ${ }^{11}$ that in the aqueous solution cis-aconitic acid was isomerized completely after boiling for five minuntes and mostly warming for ten minutes at $65^{\circ} \mathrm{C}$, and that the isomerization was especially rapid in acidic or alkaline solution. ${ }^{3}{ }^{12}$ ) Therefore, it was considered that trans-aconitic acid was produced by isomerization of cis-aconitic acid during the separation processes and was not a true intermediate of GA metabolism. In order to examine this possibility the ether extract was examined by paperchromatography, and $R_{F}$ values of the components and authentic cis- and trans-aconitic acids were compared. It was found that $\mathrm{C}$, which was not separated free from $A$ by the subsequent column chromatography and was considered to be liable to decompose, had the same $R_{F}$ value as cis-aconitic acid.

\section{Quantitative Determination of Intermediates.}

All the substances found as the intermediates of GA metabolism are members of the tricarboxylic acid

11) C. Martius, Z. Physiol, Chem., 247, 104 (1937)

12) H. A. Krebs and L. V. Eggelston, Biochem. J., 38, 426 (1944). 
cycle. An ether extract of the reaction mixture of GA under fluoroacetate inhibition was analyzed for the intermediates by the method of Varner. ${ }^{9)}$ The reaction mixture of $\mathrm{GA}$ under arsenite inhibition and that of citric acid under fluoroacetate inhibition were also analyzed. In the following experiments, all the processes were performed at as low temperature as possible and excessive acidification was avoided to prevent the isomerization of the cis-acid. Incubation mixtures under each inhibition were incubated at $30^{\circ} \mathrm{C}$ for forty-one hours under shaking and the decomposition products were extracted at $\mathrm{pH} 2.0$ with ether for one hundred and twenty hours. Each about $400 \mathrm{ml}$ of the ether extract was dried with sodium sulfate and the ether was distilled off under vacuum. The residues obtained were used for quantitative

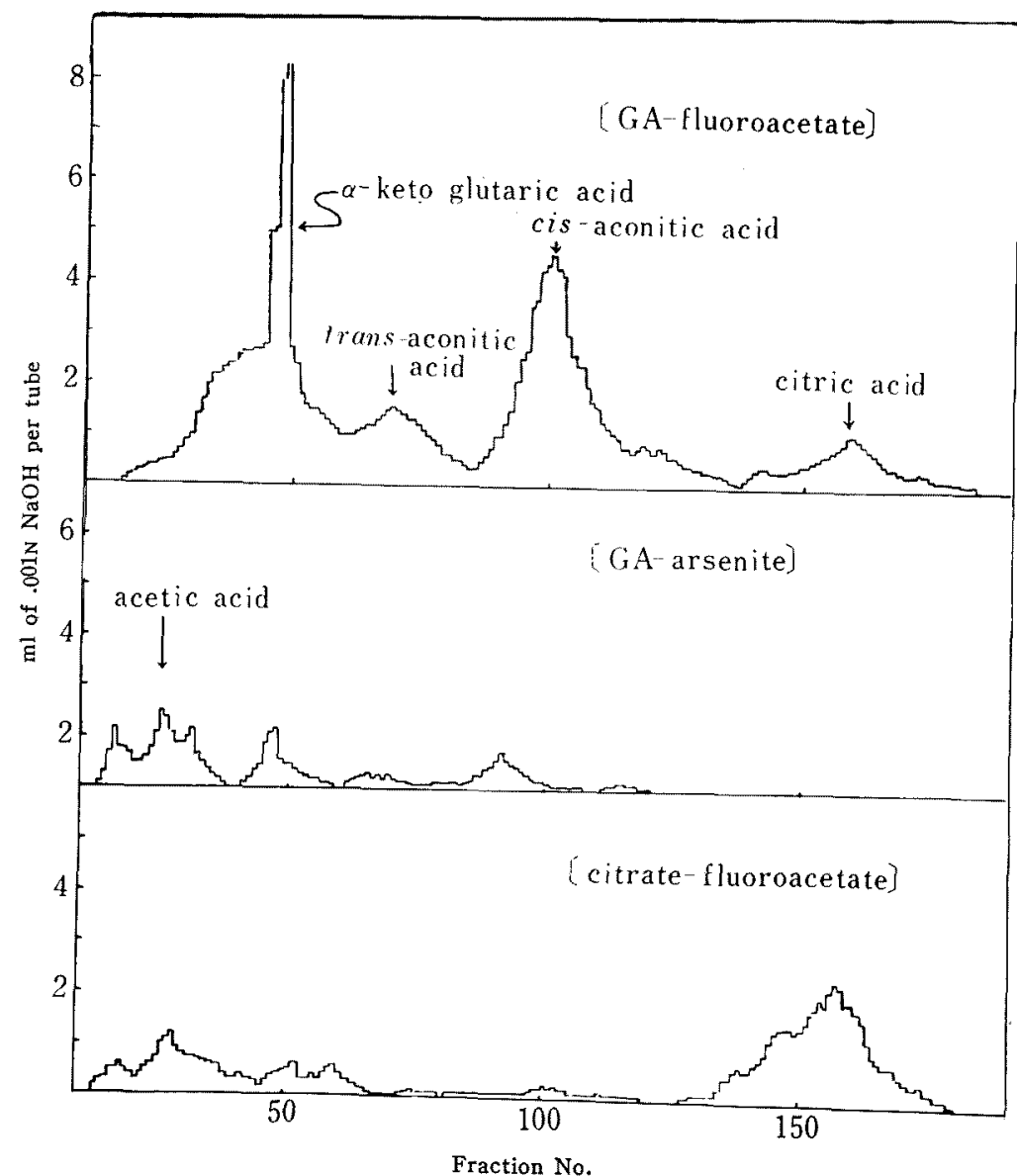

FIG. 3. Quantitative Determination of Organic Acjds from the Reaction Mixtures Containing the Inhibitors.

Reaction mixture:

GA-fluoroacetate system:

GA-arsenite system:

Components contained.

$1 \mathrm{~mm}$ GA, $0.1 \mathrm{~mm}$ fuoroacetate, $1 \mathrm{~g}$ lyophilized cell,

Citrate-fluroacete $1 \mathrm{mM} \mathrm{GA,} 0.1 \mathrm{mM}$ arsenite, $1 \mathrm{~g}$ lyophilized cell.

Citrate-fluoroacetate system: $1 \mathrm{~mm}$ citrate, $0.1 \mathrm{mM}$ fuoroacetate, $1 \mathrm{~g}$ lyophilized cell.

Each reaction mixture in a final volume of $100 \mathrm{ml}$ at $\mathrm{pH} 5.5$ was incubated at $30^{\circ} \mathrm{C}$ for forty-one hours under shaking. Each ether extract loaded on a silica gel column $(1.2 \times 25 \mathrm{~cm})$ was eluted with $200 \mathrm{ml}$ of $5 \%, 270 \mathrm{ml}$ of $15 \%, 200 \mathrm{ml}$ of $25 \%, 600 \mathrm{ml}$ of $50 \%$, and $300 \mathrm{ml}$ of $50 \% n$-butanol in chloroform. (V/V) saturated with $0.5 \mathrm{~N} \mathrm{H}_{2} \mathrm{SO}_{4}$ successively. The flow rate was $80 \mathrm{ml}$ per hour and the each fraction of $3.3 \mathrm{ml}$ was titrated with $0.01 \mathrm{~N} \mathrm{NaOH}$ with phenol red as the indicator under vigorous stirring. 
determination. The results are shown in Fig. 3. In the GA-fluoroacetate system, cis-aconitic acid, $\alpha$-ketoglutaric acid and small quantities of citric acid and transaconitic acid were found. When both aconitic acids were regarded as cis form, the molar ratio of cisaconitic acid, $\alpha$-ketoglutaric acid and citric acid was about 5:5:1. In the GA-arsenite system, $\alpha$-ketoglutaric acid did not accumulate and, in the citric acid-fluoroacetate system, cis-aconitic acid did not accumulate.

\section{DISCUSSION}

It was known that tricarboxylic acid cycle is the only metabolic pathway for formation of cis-aconitic acid and existence of tricarboxylic acid cycle has been observed in Aspergillus niger. ${ }^{13}$ It has been reported that the following reactions, I and II, in tricarboxylic acid cycle proceed by the action of aconitase and at equilibrium the ratio of citric acid, cis-aconitic acid and isocitric acid is $89.5: 4.3$ $: 6.3 \%{ }^{14}$

citric acid $\stackrel{\mathrm{I}}{\rightleftarrows}$ cis-aconitic acid $\stackrel{\mathrm{II}}{\rightleftarrows}$ isocitric acid

It has also been reported that fluoroacetate, an inhibitor for aconitase, competitively inhibits reaction I specifically. Therefore, cisaconitic acid cannot be formed from citric acid through reaction $I$. The present result with the citric acid-fluoroacetate system agrees with this mechanism. In the GA-fluoroacetate system, isocitric acid did not accumulate. Therefore cis-aconitic acid can not be the product through the reaction II. From these results, cis-aconitic acid found in the present study must have been produced through a pathway other than tricarboxylic acid cycle. Difficulty in securing the decomposing-enzyme system in a cell-free form made the study of its mechanism difficult but it was observed previously that fission of the benzol nucleus of GA proceeds with consumption of atomospheric oxygen. ${ }^{6)}$ It is conceivable that GA would be decomposed by the same kind of mechanism as in the case of oxidative decomposition of catechol reported by Hayaishi et al. ${ }^{7 \cdot 15}$ Therefore the schema for GA decomposition is proposed in Fig. 4.
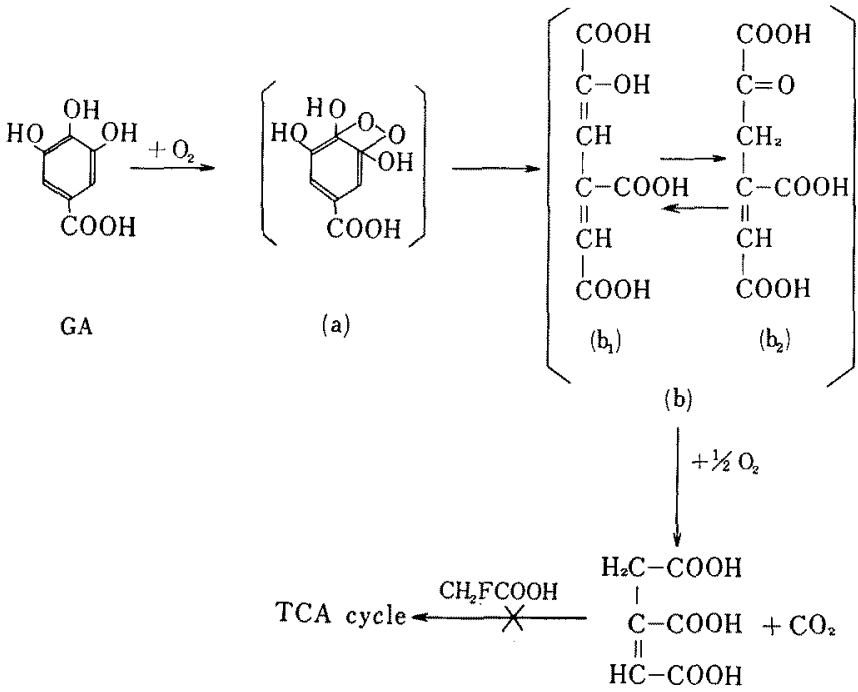

FIG. 4. Proposed Mechanism of GA Decomposition.

13) M.N. Mickelson and M.N. Schuler, J. Bacteriol., 65, 297 (1953).

14) H. A. Krebs and L. V. Eggelston, Biochem. J., 37, 334 (1943).
15) O. Hayaishi and Z. Hashimoto, Med. I. Osuka Univ. $2,33(1950)$ 
In this schema GA is exidized to peroxide(a) for aconitase such as inhibitors for $\mathrm{SH}$ by an oxygenase with atomospheric oxygen. enzymes and ferrous ion also appear to inhibit The peroxide is then decomposed to the tri- the enzyme which decomposes the benzol carboxylic acid $\left(b_{1}\right)$, which is tautomerized to nucleus of GA. This would seem to indicate $\left(b_{2}\right)$ form easily, and the two forms are in an equilibrium state. The $\operatorname{acid}\left(b_{2}\right)$ is decarboxylated to cis-aconitic acid by an oxydative decarboxylase.

Since magnesium ion combines with fluoroacetate to make a complex compound, the accumulation of $\alpha$-ketoglutaric acid under fluoroacetate inhibition suggests the inhibition of $\alpha$-ketoglutaric decarboxylase due to the removal of magnesium ion. The inhibitors the reason why the fluoroacetate inhibition was the only way to accumulate cis-aconitic acid by these cell preparations.

Acknowledgement. The author express his sincere gratitude to Prof. Y. Oshima for his helpful guidance throughout this work, and to Dr. M. Fujisawa and Dr. N. Sugimoto of Osaka Research Laboratory, Tanabe Seiyaku Co., Ltd., for their kind encouragement. 